\title{
Word StRESS SYSTEM OF THE SARAIKI LANGUAGE
}

\section{Firdos ATTA}

Lasbela University of Agriculture, Water and Marine Sciences, Pakistan

firdosmalghani@gmail.com

\begin{abstract}
This study presents an Optimality-Theoretic analysis of Saraiki word stress. This study presents a first exploration of word stress in the framework of OT. Words in Saraiki are mostly short; secondary stress plays no role here. Saraiki stress is quantity-sensitive, so a distinction must be made between short and long vowels, and light and heavy syllables. A metrical foot can consist of one heavy syllable, two light syllables, or one light and one heavy syllable. The Foot structure starts from right to left in prosodic words. The foot is trochaic and the last consonant in Saraiki words is extra metrical. These generalizations are best captured by using metrical phonology first and Optimality constraints later on.
\end{abstract}

Keywords: Saraiki, quantity-sensitive, Optimality Theory, trochaic structure, Metrical Phonology

\section{Povzetek}

Ta študija predstavlja analizo besednega naglasa v sarajskem jeziku (sarajščina, angl. Saraiki) v okviru optimalnostne teorije. Besede v sarajščini so večinoma kratke; sekundarni stres ne igra nobene vloge. Besedni naglas je količinsko občutljiv, razlikujemo med kratkimi in dolgimi samoglasniki ter lahkimi in težkimi zlogi. Stopica je lahko sestavljena iz enega težkega zloga, dveh lahkih zlogov ali enega lahkega in enega težkega zloga, v zapisani prozodični besedi se začnejo na desni in se širijo proti levi. Stopica je vedno trohejska in zadnji soglasnik sarajski soglasnik v prozodični besedi je zunaj metričen. Omenjene posplošitve je najbolje zajeti tako, da najprej uporabimo metrično fonologijo in zatem omejitve optimalnostne teorije.

Ključne besede: Saraiki, količinska občutljivost, optimalnostna teorija, trohejska zgradba, metrična fonologija 


\section{Introduction}

The analysis of stress remains a 'hot debate' in phonology. Stress refers to the phonetic prominence of one or more syllables in the prosodic word. One syllable in the prosodic domain of a word often seems more prominent than others, where phonetic prominence can be indicated by different phonetic cues: pitch, length, and loudness, or a combination of these. Cross-linguistic variation concerning stress makes it complicated to analyze: factors that play a role are, among others, the stress domain, syllable weight, the role of edges, and whether or not secondary stress occurs (see; Beckman (1986); Halle and Vergnaud (1987); Hayes (1982, 1995), among many others). In the past, such factors were analyzed by 'parameter settings' (Hayes, 1980), but this approach has largely been replaced by OT constraints taking over these functions.

Kager (1999) lists several cross-linguistic properties of word stress: (i) culminativity, i.e. words tend to have only a single peak, (ii) demarcativity, i.e. stress is usually located at a word margin, (iii) rhythmicity, i.e. stress usually alternates and (iv) quantitysensitivity, which refers to the fact that in some languages a heavy syllable in a word (i.e. a syllable with a long vowel, or a closed syllable) attracts stress. In other, quantityinsensitive languages, weight is irrelevant for stress assignment. Quantity-insensitive stress can be further divided into two categories: either stress is fixed on some syllable at or near the edge or it is rhythmically assigned. Tryon (1970) provides an example from the Australian language Maranungku, which has a rhythmic stress pattern. In this language, primary stress is located on the first syllable and secondary stresses are assigned to odd-numbered syllables thereafter. In some cases, a final syllable is always stressless, for example in Pintupi (Hansen \& Hansen, 1978).

A wide variety of stress systems are reported in the context of fixed stress systems and free stress systems. Turkish is one of the documented languages which have fixed primary stress at the final syllable of the word (Inkelas, 1999; Sezer, 1981). Likewise, Finnish places stress on the syllable in the initial position (Anttila, 1997), without taking into account the syllable weight and syllable structure. Hence such languages are insensitive towards quantity, keeping an edge-oriented stress system. However, there are also languages with weight edge-oriented stress systems, such as the Murik language (Kager, 2004). In the domain of free stress systems, languages carry stress on random positions within a word. In such languages, morphology might influence the prosodic structure, as, in the Pashto language (Shafeev, 1964). Saraiki appears to be an edge-oriented quantity-based stressed language. Not all details are known, and the influence of morphology has not yet been well analyzed. The phonetic cues of stress also do not appear to be quite the same (but some basic notions are given) as in a stress-timed language like English. The phonetic cues, pitch, duration, and intensity are considered as the basic notions of stress in English. Nevertheless, in Saraiki stress 'pitch rise and rising intensity' are the phonetic cues (Atta, van de Weijer, and Zhu, Accepted). Thus, this article should be seen as the first step towards an analysis of the Saraiki stress, 
phonologically. Other studies in the literature are related to different aspects of Saraiki language (see Atta, 2019; Shackle, 1976). Saraiki belongs to the family of Indo-Aryan family and this study is limited to the variety of the Saraiki, viz. central Saraiki, spoken in Pakistan. The OT constraints we will use will be discussed in the following sections.

This article is arranged as follows: in the next section, a brief introduction to Saraiki syllable structure is given. This will be elaborated here with a specific view of the function of syllable structure for stress assignment. The next part covers the analysis of Saraiki word stress within the OT framework. The last section concludes it.

\section{Syllable structure and the status of moras in Saraiki}

The role of syllable structure and syllabification is fundamental in shaping the stress system of quantity-sensitive languages. Saraiki is rich in syllable structure; the following are the possible syllable structures in Saraiki:

\begin{tabular}{|c|c|c|c|c|}
\hline \multirow{3}{*}{\multicolumn{2}{|c|}{$\begin{array}{l}\text { (1) V/VV /a/ } \\
\text { CV/CVV /tũ/ } \\
\text { VC/VVC /utnt }\end{array}$}} & 'come' & /əо/ & 'come in' \\
\hline & & 'you' & /piu/ & 'father' \\
\hline & & 'camel' & /əok $/$ & 'difficulty' \\
\hline CVC & /beh/ & 'sit' & $/ k^{h} \partial s /$ & 'snatch' \\
\hline CCVC & /druk/ & 'run' & /trut/ & 'break' \\
\hline CVCC & /limb/ & 'plaster' & $/ p \wedge n d^{h} /$ & 'distance' \\
\hline CCV & $/ \mathrm{k}^{\mathrm{h}} \mathrm{ri} /$ & 'stop' & /krĩl & 'will do' \\
\hline VCC & /əmb/ & 'mango' & /uns/ & 'love' \\
\hline CCVCC & /draxt/ & ' 'tree' & /drust/ & 'right' \\
\hline
\end{tabular}

Saraiki prohibits 'CCC' in initial and final position and structures of ' $V V C C$ ' or 'CCVV' are not permitted. What is crucial is that Saraiki has a phonemic contrast between long and short vowels. In the examples below long vowels are indicated by length mark (:) while short vowels are given without this length mark. The following examples illustrate this:

(2)

$\begin{array}{ll}\text { pi:r 'pain' } & \text { pir 'saint' } \\ \text { tu:l 'long' } & \text { tol 'determined' } \\ \text { mal 'goods' } & \text { mal 'dirt' }\end{array}$


Though, the quality difference (tense/lax) ${ }^{1}$ is used in English to represent the (phonetic) contrast of long and short vowels without any length mark and in Saraiki, the peripheral vowels are longer than the central vowels (Shackle, 1976). However, in Saraiki the vowels are differentiated based on quantity (long/short) with length marks. So, long vowels in Saraiki have two morae and short vowels have one mora. Likewise, the distinction between short and long vowels is commonly made in terms of mora in metrical phonology: short vowels have one more, long vowels have two (Hayes, 1995):

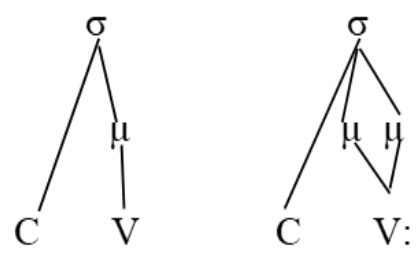

Finally, in most languages closed syllables count as equally heavy as syllables with long vowels. In terms of mora, both are therefore represented with two morae:

(4)

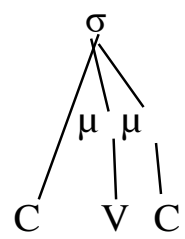

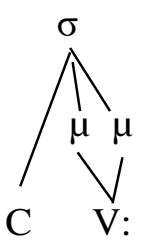

Hence, Saraiki has a potential weight contrast between light and heavy. Quantity here refers to either the weight or the length of the syllable. In metrical phonology, the moraic theory (Hayes, 1982) is widely used to assign a weight to the syllable as it is a crucial element in stress assignment in many quantity-sensitive languages. This theory suggests that in syllable structure, the onset does not carry weight while the nucleus always does and the coda might. In this way, syllables are distinguished between light and heavy (McCarthy, 1986). As suggested by McCarthy, open syllables with a short vowel are always considered as light (i.e. have one mora), whereas closed syllables may be heavy or light subject depending on the language: in some languages these count as heavy (two morae), in other languages they count as light (one mora). Languages in which they are heavy are said to have "weight by position".

\footnotetext{
${ }^{1}$ The vowel distinction is normally called as long and short in British English, however, in North America Tense and Lax are common. In English long-short and tense-lax go together and in other languages, it might be independent.
} 
In Saraiki, concerning syllable structure, it is of interest that no second syllable (which is usually also the final syllable) is without an onset. Sometimes gemination occurs to satisfy this onset requirement, for instance, /ommă/ 'mother' and /obba/ 'father'. Sometimes to satisfy the stress requirements gemination is noted too (see Shackle, 1976, p.27).

Since syllables in Saraiki are either open or closed in moraic representation, Saraiki can differentiate syllables in terms of their weight, based on the phonemic contrast between long and short vowels and syllable structure. A moraic representation to clarify the idea is illustrated here:

(5)

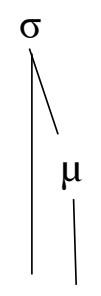

C V

Light

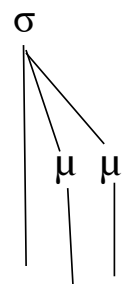

C V V

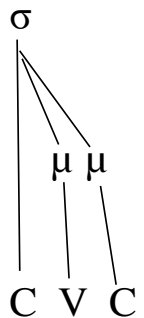

$\mathrm{H}$

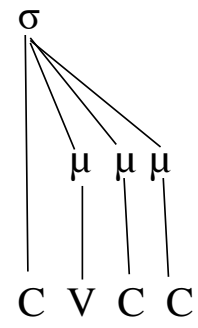

super $\mathrm{H}$

Thus, the above moraic representation suggests that a mono-moraic syllable is light (L), a bimoraic one is heavy (H). Standard German (Hall, 2002) distinguished three or more than three moraic syllables, which are known as super-heavy syllables.

Some elements do not take part in prosodic structure, therefore, such prosodic units are considered as extra metrical in the initial or final position of the prosodic word. The concept of extrametricality was first introduced by Liberman and Prince (1977) and comprehensively elaborated by Hayes (1995) later on;

a) Elements like a syllable, foot, and the segment can be extra metrical.

b) Extrametricality occurs on the right or left edge of a word.

c) The right edge is unmarked for extrametricality.

Though these rules apply in many languages such as English (Hayes, 1982), Arabic (McCarthy, 1979), etc., questions may be raised in some situations. For instance, in quantity-sensitive language, in the CV.CVC structures the last C may be extrametrical but in the CV.CVV the last V (or the mora of a vowel) may not be, although the weight of both syllables is equal. If the right edge is unmarked for extrametricality, then for a trochaic language, a mora of a final VV might be extra metrical as it has no role in the prosodic structure. We are not trying to fix this issue here as this is beyond our scope of study and this requires further theoretical investigation. Moreover, in Saraiki, we do not have such final syllable structures to face the ambiguity. For the time being, we are following the existing practice of extrametricality. Thus, we need to be careful 
about the role of extrametricality in different languages, and we will examine its role carefully in Saraiki.

Taking into consideration the observations of McCarthy (1979) for Arabic concerning syllable weight, we assume that in Saraiki all open syllables are light and closed syllables may be light or heavy Whereas closed syllables with VV (long vowel or diphthong) or VCC are heavy. Generally, the moraic representations of words cited from Saraiki are presented below:

(6)
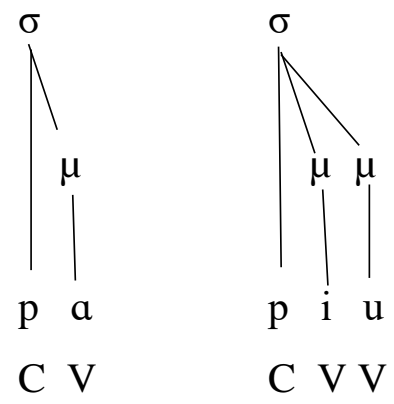

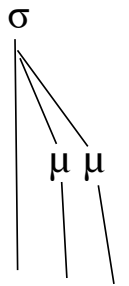

$m$ ə $t$

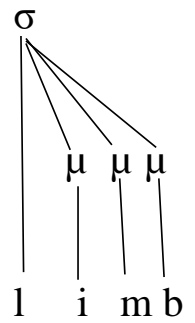

C V C C

The last example requires some discussion as this contains three moras. According to Hayes (1980), a foot can contain maximally two moras. Here the point of interest is a super-heavy syllable in Saraiki. As moraic theory demands that only two moras can make a foot therefore, the last mora is considered as extra metrical. The above example also shows that in Saraiki, the right edge of the prosodic word is extrametrical.

Since biconsonantal clusters are absent in medial position (especially as coda but might be the onset of next syllable) of the word. Such clusters, when they occur in medial position are split between two syllables i.e, $/ \mathrm{k}^{\mathrm{h}} \partial t \cdot \mathrm{ra} /,\left[{ }^{\mathrm{k}} \mathrm{k}^{\mathrm{h}}\right.$ ə.tra] ' $\cot ^{\prime}$ ' and /su. 'hã.frã/ , [*su. 'hãf.rã] 'moringa tree'. An interesting fact regarding syllable structure at medial position is that consonant cluster becomes the onset of the following syllable only if the preceding syllable has a long vowel (peripheral vowel) as the nucleus. Thus the division of consonant cluster at medial position suggests that extrametricality might play a role at the right edge. We will therefore assume that in Saraiki the last consonant in CVC and VCC is extrametrical $(\langle C>)$. This means that in Saraiki we find only two types of syllables, light $(\mathrm{L})$ and heavy $(\mathrm{H})$, and their moraic representations look like this: 
(7)

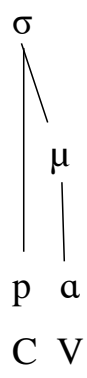

$\mathrm{L}$

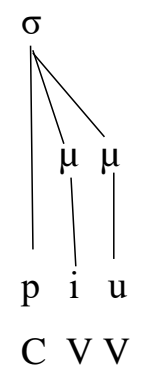

$\mathrm{H}$

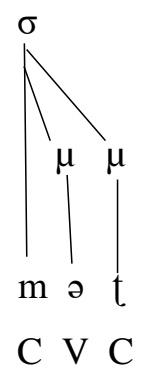

$\mathrm{H}$
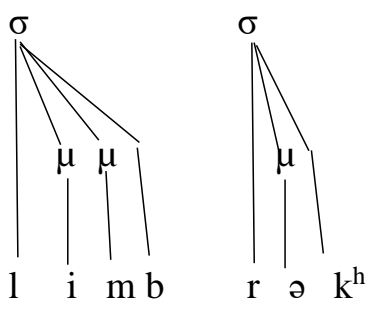

$\mathrm{C}$ V C $<\mathrm{C}>\mathrm{C} \mathrm{V}<\mathrm{C}>$

$\mathrm{H}$

After having established the above syllable structure, we move on towards foot construction in the next section.

\subsection{Foot construction and stress assignment in Saraiki}

In prosodic structure, the foot is crucial for stress assignment. There are two main types of feet, trochees (strong weak) and iambs (weak strong), which are further divided into subtypes, as proposed by Hayes (1995). Here ' $\mathrm{L}$ ' denotes a light syllable and ' $\mathrm{H}$ ' stands for a heavy syllable.

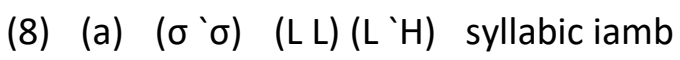

(b) $(\mu ` \mu)(H) \quad$ moraic iamb

(c) $\left({ }^{\circ} \sigma \sigma\right) \quad(\mathrm{LL})(\mathrm{H} \mathrm{H})$ syllabic trochee

(d) $(\mu \mu)(\mathrm{H}) \quad$ moraic trochee

Feet are represented by parentheses and the stress mark in the foot indicates its trochaic or iambic nature (Cohn \& McCarthy, 1998; Selkirk, 1980). The hierarchy of prosodic categories is given as:

(9) Prosodic word

$\downarrow$

Feet

$\downarrow$

Syllable

$\downarrow$

Mora

Generally, whether monosyllabic words are light or heavy, they are always stressed therefore, no need to list such words in Saraiki for stress assignment. 
Now let us turn to disyllabic words. Data concerning stress is given in (10). Note that a trill sometimes occurs as a free variant of tap/flap and as a syllabic consonant after dental plosives (Atta, van de Weijer, and Zhu, 2020). Therefore, one can observe these three forms in the data below.

(10) a. disyllabic words with CV.CV

\begin{tabular}{|c|c|c|}
\hline pa.sa & 'side' & $(` L L)$ \\
\hline pa.la & 'cold' & $(` L L)$ \\
\hline$p^{h} a . l a$ & 'door' & $(` L L)$ \\
\hline$k^{h} a . l a$ & 'ford' & $(' L L)$ \\
\hline \multicolumn{3}{|c|}{ b. Disyllabic words with VCCCV or VVCV or CVCCV } \\
\hline ĩ:.da & 'his/her' & $(` \mathrm{H} H)$ \\
\hline$u t^{h} \cdot t^{h_{i}}$ & 'wake up' & $\left({ }^{\circ} \mathrm{H}\right)$ \\
\hline us.trii & 'clever' & $(` H \mathrm{H})$ \\
\hline iț.la & 'so much' & $(` \mathrm{H} \mathrm{H})$ \\
\hline$k^{h} \partial t \cdot r a$ & 'cot' & $\left({ }^{\prime} \mathrm{H} H\right)$ \\
\hline
\end{tabular}

From the inspection of the above data, we noted that the foot type of Saraiki is a moraic trochee. Moraic representations of examples from (10) are given in (11).

(11) (a) has two moras;

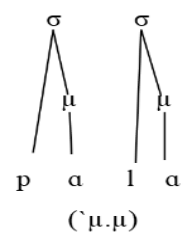

(b) has three moras $(2+1)$

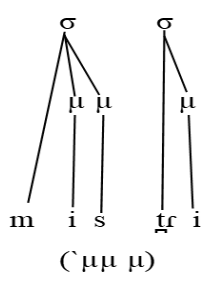

(c) three moras $(1+2)$

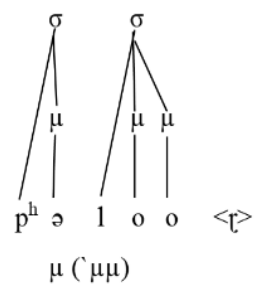


As we expected, foot structure is quantity-sensitive in Saraiki since heavy syllables construct a foot by themselves. These final heavy syllables also lead us to fix the direction of feet construction: this process starts from the right edge of the prosodic word as it is obvious from the syllable structure of disyllabic words below:

Disyllabic words with CV.CVV $<\mathrm{C}>$ or CVC.CVV $<\mathrm{C}>$

\begin{tabular}{|c|c|c|}
\hline$p^{\text {h}}$ ə. ’loo $<r>$ & 'explore' & $L\left({ }^{\prime} H\right)$ \\
\hline mə.' 'roo<r> & 'twist' & L (’H) \\
\hline sək. 'roo<r> & 'crispy' & $\mathrm{H}\left({ }^{\prime} \mathrm{H}\right)$ \\
\hline mor. 'daa $<r>$ & 'dead' & $\mathrm{H}\left({ }^{\prime} \mathrm{H}\right)$ \\
\hline טə. 'loo<r> & 'waterspout' & $\mathrm{L}(\mathrm{H})$ \\
\hline
\end{tabular}

To summarize so far, the following characteristics of Saraiki stress have been discovered:

1. Saraiki is a quantity-sensitive language since heavy syllables cannot serve in the weak position of a stress foot.

2. In the case of two light syllables stress falls on the left ( $L L$ ).

3. If the foot structure is (Schmidt), the heavy syllable will attract stress.

4. Syllables with schwa or light syllables never attract main stress and heavy syllables always do.

5. The foot is trochaic and feet are assigned from right to left

If these considerations are correct, we predict that stress would fall on the medial syllable in trisyllabic words. Data for such words are given in (12), noting that there are far fewer examples of this than disyllabic words.

(12) Trisyllabic words with V.CV.CV or CV.CV.CCV
u. 'ba. I' 'haste'
su. `hã.frã 'moringa tree'
bv. `ha.ri 'broom'
$L(` L L)$

We see that our prediction is borne out. In fact, concerning trisyllabic words, there are no counterexamples (e.g. with different syllable structures) in Saraiki. 
(13)

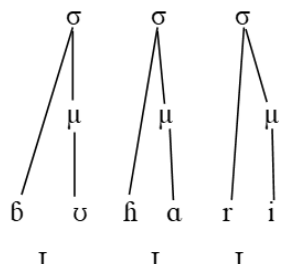

Now let's turn to the OT analysis of these examples.

\section{OT analysis of Saraiki Stress}

This section shows how the Saraiki stress system is captured in Optimality Theory. The above characteristics of Saraiki stress can be 'translated' into a metrical constraint ranking. Before an analysis of Saraiki stress, we would like to introduce some of the relevant constraints. For example, in languages in which stress is subject to weight sensitivity, the constraint WSP (weight to stress position) is high ranked. This constraint is defined as follows:

(14) WSP "heavy syllables are stressed". (Prince \& Smolensky, 1993)

Likewise, foot construction (whether based on syllables or moras) is an essential part of stress assignment. Feet typically consist of two units (see also above). This is captured by the constraint FOOT BINARITY (FT.BIN):

(15) FOOT BINARITY (FT.BIN) "feet must be binary at syllabic or moraic level" $(\sigma \sigma)$ or $(\mu \mu)$. (Broselow, 1992)

We saw that consonant extrametricality played a role in Saraiki stress. When a language has extrametrical units, it violates WBP and MAX-IO $\mu$ and satisfies *FINAL-C$\mu$ and $* \mathbf{3} \mu$ (only for VCC\# and VVC\# but not for VC\#). All these constraints are defined as follows:

(16) $* 3 \mu \quad$ "no three moras in one syllable" (Kager, 1999)

WBP "a coda consonant is moraic" (Hayes, 1989)

*FINAL-C- $\mu$ "the final mora is extrametrical" (Hayes, 1989)

MAX-IO $\mu$ "output must contain maximum input moras"

We start our analysis with monosyllabic words. Keeping in mind the basic elements of prosodic structure $(\mu)$ as given above, we assumed that the word limb 'plaster' has two moras. However, OT is free to consider other candidates ('freedom of generation'), 
e.g. with three moras (i.e. without extrametricality, or with two feet, or even without stress). Such candidates will fail because of other constraints, in particular $* 3 \mu$ and a general constraint that requires prosodic structure. The purpose to analyse monosyllabic words is to clarify the status of moraic feet in Saraiki.

\section{(17) Input: /li $\mu m \mu b \mu / * 3 \mu$ FT. BIN *FINAL-C- $\mu$ MAX-IO $\mu$ WBP \\ a. $(\operatorname{li} \mu \mathrm{m} \mu \mathrm{b} \mu)$ \\ $*$ ! * * \\ b. $(\operatorname{li} \mu \mathrm{m} \mu)<\mathrm{b}>$}

The first candidate breaches the high ranked constraints and is thus excluded from winning. The second contender, although it has two violation marks, emerges as the winner. This suggests that these two constraints are ranked low in the prosodic constraint hierarchy of Saraiki. The high position of $* \mathbf{3} \boldsymbol{\mu}$ confines structures like -VVC and -VCC- to word-medial position as extrametricality only occurs at the right edge. The examples from Saraiki, /us.tri/ 'clever' and /əo.tra/ 'poor' reflect the position of $* \mathbf{3} \boldsymbol{\mu}$ constraint in the framework of OT.

\section{(18) Input: /u $\mu$ s $\mu$ tri $\mu / * 3 \mu$ FT. BIN}

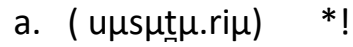

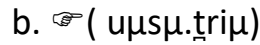

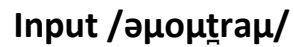

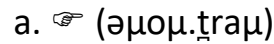

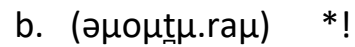

Let's now analyze a disyllabic word with a simple CV.CV structure. Rhythmically, this simple structure has two possible outputs i.e. stress on the ultimate or the penultimate. Since the stress is on the left syllable, a left-headed foot must be involved. OT expresses this with a single constraint 'FOOT-FORM trochee':

\section{FOOT-FORM trochee "foot must be left-headed"}

Since we already argued that the constraint ' $\mathrm{FT} B \mathrm{BIN}^{\prime}$ is high ranked so, the interaction of the two constraints FT.BIN and 'FOOT-FORM trochee' is illustrated as follows: 
(20) FOOT BINARITY, FOOT-FORM trochee

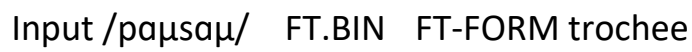

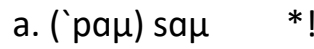

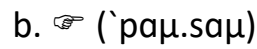

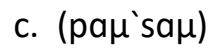

*!

Let's inspect why some applicants are defeated. Candidate (c) incurs a violation of the FT-FORM constraint, whereas the ' $a$ ' contender fatally violates FT-BIN. The ' $b$ ' candidate satisfies both these constraints and comes out as the winner. If we compare the two winners in the above two tableaux, a slight difference in the foot formation is noted, the winner in (18) (li $\mu \mathrm{m} \mu<\mathrm{b}>$ ) obeys moraic foot binarity (a foot consists of two morae and have stress on the left mora) while the second one in (20) ('pa $\mu . s a \mu$ ) obeys both foot binarity and moraic binarity. One strong reason in this regard is that there are no monosyllabic words with a single mora (i.e. a short vowel) in Saraiki. This follows from the analysis proposed so far. Since the prosodic words have a foot, and a foot is binary (either in terms of moras or of syllables), a monosyllabic word may have two moras. It then also follows that a word with a closed syllable (short vowel followed by a consonant), is bimoraic. This proves that Saraiki is a language that has "weight-byposition" (cf. above)

Let's test our analysis so far on another category of disyllabic words that have structures like CVC.CVVC or CV.CVVC. These kinds of data are special as the analysis will help to look at different issues related to Saraiki stress. The first notable thing is the stress assignment on such words i.e. $(\mathrm{H} \mathrm{H})$ and $(\mathrm{LH})$. Previously, we saw only one kind of words i.e. $(L L)$, therefore no dispute is noted, our coming discussion will deal with words having other than ( $L \mathrm{~L})$ structure. Examples for such structures and their moraic representation are given below:

$$
\begin{array}{lll}
\mathrm{p}^{\text {hə. } ` l o o<r>} & \text { 'explore' } & \mathrm{L}\left({ }^{\prime} \mathrm{H}\right) \\
\text { mə. 'roo }<\mathrm{r}> & \text { 'twist' } & \mathrm{L}\left({ }^{\prime} \mathrm{H}\right) \\
\text { sək. 'roo }<\mathrm{r}> & \text { 'crispy' } & \mathrm{H}\left({ }^{\prime} \mathrm{H}\right) \\
\text { mor. 'daa }<\mathrm{r}> & \text { 'dead' } & \mathrm{H}\left({ }^{\prime} \mathrm{H}\right)
\end{array}
$$

(22) Moraic representation

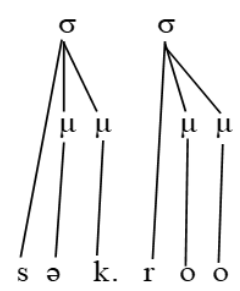

$\mathrm{H}$

$\mathrm{H}$
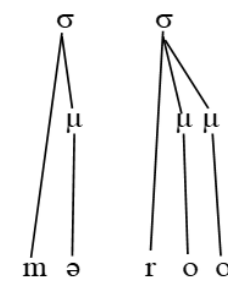

L $\mathrm{H}$ 
Recall the characteristics of Saraiki stress: it appeared to be quantity-sensitive which means heavy syllable will attract stress (the constraint WSP is ranked high). Hence, in case of an unequal weight $(\mathrm{LH})$ for quantity sensitive languages, it is easy to predict stress assignment while in the case of equal weight $(H \mathrm{H})$ of syllables a competition is noted. In the first tableau, the word 'limb' violates foot binarity so the last ' $\mathrm{C}$ ' is considered as extrametrical to avoid this violation. It indicates that the last ' $\mathrm{C}$ ' in CVVC' and CVC is considered as extrametrical in Saraiki. This means that such structures violate WBP and MAX-IO- $\mu$ as given above in (18). Two characteristics quantity and trochaic stress, suggest the superiority of right edge alignments in ' $\mathrm{LH}^{\prime}$ structures. The alignment constraint for the right edge in OT is ALL FT-R and the constraint PARSE SYL demands all syllables must be parsed into feet; these are given in (22). Let's take a word with (LH) structure first for analysis:

(23) ALL-FT-R "all feet must be right aligned in prosodic word" PARSE-SYL "syllables must be parsed into feet"

\begin{tabular}{|c|c|c|c|c|c|c|c|c|c|}
\hline 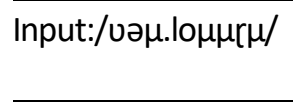 & $* 3 \mu$ & FT.BIN & FTFORM & $\begin{array}{l}\text { *FINAL- } \\
C-\mu\end{array}$ & $\begin{array}{l}\text { ALL } \\
\text { FT-R }\end{array}$ & WSP & $\begin{array}{l}\text { MAX- } \\
10-\mu\end{array}$ & PARSE-SYL & WBP \\
\hline a. $v ә \mu .(' \operatorname{lo} \mu \mu)<>>$ & & & & & & & $*$ & $*$ & $*$ \\
\hline b. $($ & & & $* !$ & & & & $*$ & & $*$ \\
\hline c. $(v \partial \mu) \cdot \operatorname{lo} \mu \mu<r>$ & & $* !$ & & & $*$ & & $*$ & $*$ & $*$ \\
\hline 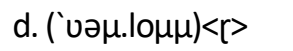 & & & & & & $* !$ & $*$ & & $*$ \\
\hline e. $\left(v ә \mu .{ }^{`} l o \mu \mu r \mu\right)$ & $* !$ & & $*$ & $*$ & & & & & \\
\hline
\end{tabular}

The first candidate emerges as optimal and has violations of three low ranked constraints. This winner also suggests that it is only necessary for the foot to follow foot binarity either at the syllable or moraic level. The satisfaction of FT-FORM requires regenerating feet on the moraic level. As the extrametrical consonant is associated with the next syllable in Saraiki, it suggests the structure is something like a stressed to unstressed syllable. Therefore, the optimal winner means that binary feet are favored while leaving the remaining syllable unparsed. The second candidate though has three violation labels but is not a winner. Since none of the other candidates survives under this constraint ranking as they bear fatal violations. The constraint ranking so far is depicted as:

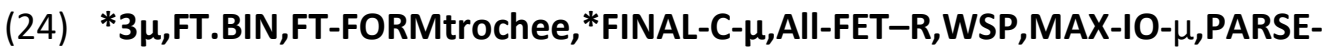 SYL,WBP}

While taking this constraint ranking a word of structure $[\mathrm{H} \mathrm{H}]$ is scrutinized. These kinds of words have five possible feet structures; (i) (`H) (`H), (ii) $\mathrm{H}$ (`H) (iii) ( $\mathrm{H}^{`} \mathrm{H}$ ) (iv) $(\mathrm{H}) \mathrm{H}$, and $(\mathrm{v})(\mathrm{H} H)$, where the preferred structure is $H\left({ }^{\prime} H\right)$ when the foot is 
regenerated on moraic level, in Saraiki. Now the point of concern is to find out the reasons, on what basis the rest of the structures are not favored? As discussed earlier, Saraiki is trochaic so those structures which oppose it are categorically ruled out in Saraiki as $(\mathrm{H} ` \mathrm{H})$. Since the structure $\left({ }^{\prime} \mathrm{H}\right)\left({ }^{\prime} \mathrm{H}\right)$ bears stresses clashes so language dislikes it and $(\mathrm{H}) \mathrm{H}$ violates another constraint ALL-FT.R so dispossessed. The rest of the candidates, $\mathrm{H}\left({ }^{\prime} \mathrm{H}\right)$, and $\left({ }^{\mathrm{H}} \mathrm{H}\right)$ have no solid reasons for eviction, at surface level. The stress assignment in quantity sensitive languages is subject to quantity and rhythmicity (Kager, 2004). Though quantity is the main factor to attract stress in a quantitysensitive language in some situations rhythm comes into play as in case of $(\mathrm{H} \mathrm{H})$ structures. Extrametricality in Saraiki is not limited to regulate foot structure only but rather it helps to determine the rhythmic structure of prosodic words which has strongweak rhythmicity. To regulate such structures, OT introduced 'RHTYPE-T (feet have initial prominence)' and RH-CONTOUR (a foot end on strong-weak contour at moraic level) as constraints WSP is not enough to handle the situation. In reality, these rhythmic constraints are related to the vowel quantity. WSP is only affected when ' $\mathrm{L}$ ' syllable received stress in the presence of ' $\mathrm{H}$ ' but a violation of WSP in ' $\mathrm{HH}$ ' could not help to select either one ' $\mathrm{H}$ ' or the other in Saraiki. Thus, concerning the above data stress is noted only on long vowels (never on short vowels) in Saraiki. All the examples of structure 'CVC.CVVC' and 'CV.CVVC' have short vowel unstressed. So a constraint '*LONG-V unstressed' dominates WSP. With the addition of this constraint we look at the winner of next tableau:

\begin{tabular}{|c|c|c|c|c|c|c|c|c|c|}
\hline *LONG-V unstressed & no & wel & sse & 17 & plese & e & $\mathrm{m}$ & owe & \\
\hline $\begin{array}{l}\text { Input: } \\
\text { /sə } \mu k \mu . r o \mu \mu r \mu /\end{array}$ & $\begin{array}{l}* 3 \mu-\text { FT.BIN } \\
\sigma\end{array}$ & $\begin{array}{l}\text { FTFORM } \\
\text { trochee }\end{array}$ & $\begin{array}{l}{ }^{*} \text { FINAL- } \\
C-\mu\end{array}$ & $\begin{array}{l}\text { All } \\
\text { FT- } \\
\text { R }\end{array}$ & $\begin{array}{l}\text { *LONG- } \\
\mathrm{V}_{\text {unstressed }}\end{array}$ & WSP & $\begin{array}{l}\text { MAX- } \\
10-\mu\end{array}$ & $\begin{array}{l}\text { PARSE- } \\
\text { SYL }\end{array}$ & WBP \\
\hline $\begin{array}{l}\text { a. } \\
\text { so } \mu k \mu .(\text { ro } \mu \mu)<r>\end{array}$ & & & & & & & $*$ & $*$ & $*$ \\
\hline b. $\left(\right.$ sə $\left.\mu k \mu .{ }^{`} r o \mu \mu\right)<r>$ & & $* !$ & & & & $*$ & $*$ & & $*$ \\
\hline c. $\left({ }^{\prime} s \partial \mu k \mu\right) \cdot r o \mu \mu<r>$ & & & & $* !$ & & & $*$ & $*$ & $*$ \\
\hline d. $\left({ }^{\prime} s \partial \mu k \mu . r o \mu \mu\right)<r>$ & & & & & $* !$ & $*$ & $*$ & & $*$ \\
\hline
\end{tabular}

Before fixing the label of the optimal winner, let's analyze the defeated candidates first. The second participant though has four violation tags and is rejected because of the fatal violation of foot form which is not conforming to the language requirements. The ' $c$ ' candidate is defeated at its first step by incurring the violation of foot direction. Though the last candidate follows the basic prosodic structure of language it meets a fatal violation. In Saraiki, stress is never assigned to a syllable with schwa or syllables that have short vowels, in the presence of long vowels. It is also common in many languages as in Dutch (van Oostendorp, 2012). Thus the ' $d$ ' candidate could not be the winner. The first contender has three violation marks but is the winner. These are not 
the minimal violations incurred by the first participant as compared to the violations of any other competitors but lack any fatal violation. A parallel look at candidates ' $a$ ' and ' $d$ ' presents the involvement of one constraint, based on which one is a winner and the other is not. This is '*LONG-Vunstressed' which is responsible to evaluate the optimal winner in such syllable structures. Thus the role of WSP is confusing as suggested by Kager (2004), who suggested in ( $\mathrm{H} \mathrm{H}$ ) foot WSP is violated either the stress falls on the first syllable or second. However, this concept is not clear in some situations: it is obvious, one foot can carry one stress, and automatically the violation of WSP occurred where the other syllable remained unstressed. It can be only possible if syllable foot binarity stands low in ranking in language. The matter of fact is this constraint is ranked high in Saraiki. Thus the motivational factor in Saraiki is not the WSP rather vowel quantity determines the stress in case of equal syllable weight. Thus we can get the final ranking hierarchy for disyllable words in Saraiki language as follows:

\section{$* 3 \mu$,FT.BIN,FT-FORMtrochee,All-FT-R, *FINAL-C- $\mu$, * LONG-V ${ }_{\text {unstressed, WSP,MAX- }}$ IO- $\mu$, PARSE-SYL,WBP}

Since any constraint ranking represents the language as a whole, it should be equally applicable in all words of the language. Initially, we extend this to words with three syllables. As discussed earlier, the structure of three-syllable words is very simple and they are limited in number. These words are limited to CV.CV.CCV and CV.CV.CV (there is no counterexample at monomorphemic) and attract stress on the penult. Under the same constraint ranking a word from this category is given in the tableau below:

(27)

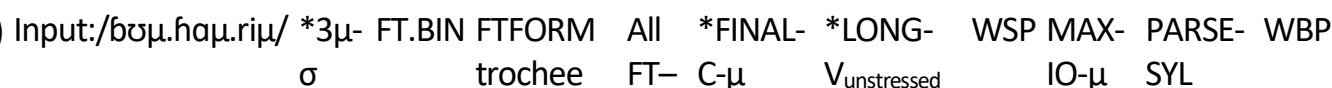
$\begin{aligned} & \text { trochee } \mathrm{FT} \\ & \mathrm{R}\end{aligned}$

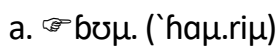

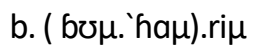

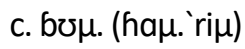

The constraint ranking, for three-syllable words, appears to be appropriate like it was with the disyllable structures. The analysis looks as simple as the syllable structure itself is. Candidate 'a' appears as optimal as it has the minimum violations. The rest of the contenders bear fatal violations of high ranked constraints, and thus rejected from the winning.

To summarize the above analysis, we come up with the conclusion that Saraiki word prosody has the following constraint ranking and characteristics: 


\section{$* 3 \mu \gg>$ FT.BIN $\gg$ FT-FORMtrochee $\gg>$ All-FT-R $>*$ FINAL-C- $\mu \gg>*$ LONG- Vunstressed $>$ WSP $\gg$ MAX-IO- $\mu$ >PARSE-SYL $>$ WBP}

1. Saraiki is a trochaic and quantity sensitive language.

2. No short vowel is stressed in the presence of a long vowel.

3. The right edge of the prosodic word must coincide with the right edge of the grammatical word.

4. Words have only one foot: there is no secondary stress.

\section{Conclusion}

Saraiki word stress can be analyzed by using metrical phonology as well as in the context of OT in a straightforward way. The results of both theories i.e., metrical phonology and OT, lead to the conclusion that the language has a trochaic stress system and falls in the category of quantity-sensitive languages: feet are constructed based on moras. Consonant extrametricality functions at the right edge of the word. In case different syllables might bear the stress, the ones with long vowels win. Finally, stress is morphologically derived words and at sentence level requires further exploration.

\section{References}

Anttila, A. (1997). Deriving variation from grammar: A study of Finnish genitives. In R. v. H. Frans L. Hinskens, W. Leo Wetzels (Eds.), Variation, change and phonological theory (pp. 35-68). Amsterdam \& Philadelphia: John Benjamins Publishing.

Atta, F. (2019). Phonetics and Phonology of the Saraiki language: a descriptive exploration and an analysis from the perspective of Optimality Theory (Ph.D. dissertation), Shanghai International Studies University, Shanghai.

Atta, F., Weijer, J. v. d., \& Zhu, L. (2020). Illustrations of the IPA: Saraiki. Journal of the International Phonetic Association.

Beckman, M. E. (1986). Stress and non-stress accent (Vol. 7). Holland/Riverton: Foris publications.

Broselow, E. (1992). Parametric variation in Arabic dialect phonology. Paper presented at the Perspectives on Arabic linguistics IV, Amsterdam \& Philadelphia.

Cohn, A., \& McCarthy, J. (1998). Alignment and parallelism in Indonesian phonology. Working Papers of the Cornell Phonetics Laboratory 12, 6, 53-137.

Halle, M., \& Vergnaud, J.-R. (1987). Stress and the cycle. Linguistic inquiry, 18(1), 45-84.

Hall, T. A. (2002). The distribution of superheavy syllables in Standard German. The Linguistic Review, 19(4), 377-420.

Hansen, K. C., \& Hansen, L. E. (1978). The core of Pintupi grammar. Australia: Institute for Aboriginal development Alice Springs. 
Hayes, B. (1980). A Metrical Theory of Stress Rule. (Ph.D. dissertation), MIT was published in 1985 by Garland Press, New York.

Hayes, B. (1982). Extrametricality and English stress. Linguistic inquiry, 13(2), 227-276.

Hayes, B. (1989). Compensatory lengthening in moraic phonology. Linguistic inquiry, 20(2), 253306.

Hayes, B. (1995). Metrical stress theory: Principles and case studies. Chicago: University of Chicago Press.

Inkelas, S. (1999). Exceptional stress-attracting suffixes in Turkish: representations versus the grammar. In R. Kager, H. v. d. Hulst, \& W. Zonneveld (Eds.), The prosody-morphology interface (pp. 134-187). Cambridge: Cambridge University Press.

Kager, R. (1999). Optimality Theory ( $1^{\text {st }}$ ed.). Cambridge: Cambridge University Press.

Kager, R. (2004). Optimality Theory ( $2^{\text {nd }}$ ed.). Cambridge: Cambridge University Press.

Liberman, M. Y., \& Prince, A. (1977). On stress and linguistic rhythm. Linguistic inquiry, 8(2), 249-336.

McCarthy, J. (1979). On stress and syllabification. Linguistic inquiry, 10(3), 443-465.

McCarthy, J. (1986). OCP effects: Gemination and antigemination. Linguistic inquiry, 17(2), 207263.

Prince, A., \& Smolensky, P. (1993). Optimality Theory London: Blackwell.

Selkirk, E. O. (1980). The role of prosodic categories in English word stress. Linguistic inquiry, 11(3), 563-605.

Sezer, E. (1981). On non-final stress in Turkish. Journal of Turkish Studies, 5, 61-69.

Shackle, C. (1976). The Siraiki Language of central Pakistan: a reference grammar. London: School of Oriental and African studies university of London(SOAS).

Shafeev, D. (1964). A short grammatical outline of Pashto (Vol. 33). Bloomington: Indiana University.

Tryon, D. T. (1970). An Introduction to Maranungku (Northern Australia). Canberra, Australian National University.

Van Oostendorp, M. (2012). Quantity and the Three - Syllable Window in Dutch Word Stress. Language and linguistics compass, 6(6), 343-358. 